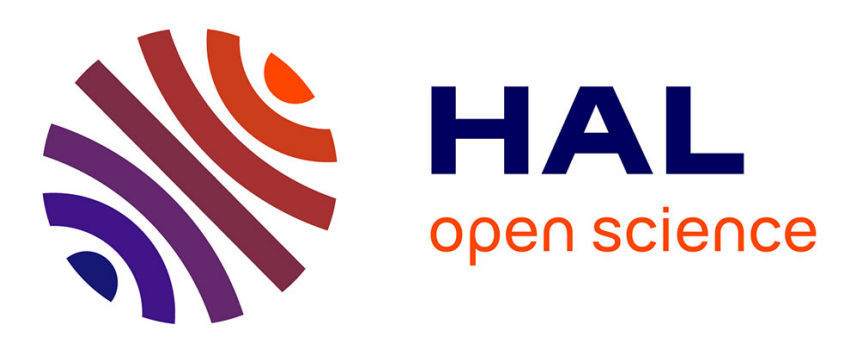

\title{
Glycosyl carotenoids from marine spore-forming Bacillus sp. strains are readily bioaccessible and bioavailable
}

Charlotte Sy, Beatrice Gleize, Stéphanie Chamot, Olivier Dangles, Frédéric

Carlin, Catherine Caris Veyrat, Patrick Borel

\section{- To cite this version:}

Charlotte Sy, Beatrice Gleize, Stéphanie Chamot, Olivier Dangles, Frédéric Carlin, et al.. Glycosyl carotenoids from marine spore-forming Bacillus sp. strains are readily bioaccessible and bioavailable . Food Research International, 2013, 51 (2), pp.914-923. 10.1016/j.foodres.2013.02.003 . hal-03202928

\section{HAL Id: hal-03202928 \\ https://hal.inrae.fr/hal-03202928}

Submitted on 20 Apr 2021

HAL is a multi-disciplinary open access archive for the deposit and dissemination of scientific research documents, whether they are published or not. The documents may come from teaching and research institutions in France or abroad, or from public or private research centers.
L'archive ouverte pluridisciplinaire HAL, est destinée au dépôt et à la diffusion de documents scientifiques de niveau recherche, publiés ou non, émanant des établissements d'enseignement et de recherche français ou étrangers, des laboratoires publics ou privés. 


\section{Glycosyl carotenoids from marine spore-forming Bacillus sp. strains are}

2 readily bioaccessible and bioavailable ${ }^{\ddagger}$

3

4 Charlotte $\mathrm{SY}^{1-5}$, Beatrice Gleize ${ }^{1-3}$, StéPhanie ChamoT $^{4-5}$, Olivier Dangles ${ }^{4-5}$,

5 Frédéric CARLIN ${ }^{4-5}$, CATHERINE CARIS VEYRAT $^{4-5}$, PATRICK Borel ${ }^{1-3 *}$

6

7

${ }^{1}$ INRA, UMR1260, "Nutrition Obesity and Risk of Thrombosis", F-13385, Marseille, France ${ }^{2}$ INSERM, UMR 1062, F-13385, Marseille, France.

${ }^{3}$ Aix Marseille Université, Faculté de Médecine, F-13385, Marseille, France

${ }^{4}$ INRA, UMR408, "Sécurité et Qualité des Produits d'Origine Végétale", F-84000, Avignon, France

${ }^{5}$ Université d'Avignon et des Pays de Vaucluse, UMR408, "Sécurité et Qualité des Produits d'Origine Végétale", F-84000, Avignon, France

e-mail adress of each author:

Charlotte Sy: sy_charlotte@ hotmail.com

Béatrice Gleize: beatrice.gleize@univ-amu.fr

Stéphanie Chamot: stephanie.chamot@avignon.inra.fr

Olivier Dangles : Olivier.Dangles@univ-avignon.fr

Frédéric Carlin : frederic.carlin@avignon.inra.fr

Catherine Caris-Veyrat : caris@avignon.inra.fr

$*$ Corresponding author:

4 address: UMR «NORT», 27 Bd Jean Moulin, 13385 Marseille cedex 5 France

25 Tel: +33 4912941 11, Fax: +33 4917821 01. E-mail: $\underline{\text { Patrick.Borel@univ-amu.fr }}$ 
27 RUNNING TITLE: Bacillus sp. strains carotenoid bioavailability.

$28{ }^{\ddagger}$ The present work has received funding from the European Community’s Seventh

29 Framework Programme. The funding was attributed to the COLORSPORE project entitled

30 New Sources of Natural, Gastric Stable, Food Additives, Colorants and Novel Functional

31 Foods (small collaborative project $N^{\circ} 207948$, topic (Bio-)Technologies for the production of

32 food additives, colorants, and flavours, KBBE-2007-2-3-03). The funding source had no

33 involvement in this publication. This publication reflects only the authors' view. The

34 Colorspore community is not liable for any use that may be made of the results. No author has

35 any conflict of interest. All authors have approved the final article. 


\section{ABSTRACT}

The main human sources of carotenoids are fruits and vegetables. Some bacteria also synthesize carotenoids that can have peculiar chemical structures that raise the question of their bioavailability in humans. HU36 and GB1 Bacillus strains contain glycosyl carotenoids that are partially acylated by linear fatty acids. The aim was to assess the bioaccessibility, the uptake efficiency and the tissue distribution of these bacterial carotenoids. $\beta$-Carotene was used as a model carotenoid for comparisons. Results of in vitro digestion experiments showed that bioaccessibility of purified extracts of bacterial carotenoids was considerably higher (about 4.5 times as high) than that of pure $\beta$-carotene. Bacterial carotenoids were also bioaccessible when digested from their natural matrices, but about 2 times less than their purified extracts. Bacterial carotenoids were absorbed by Caco- 2 with similar efficiency than $\beta$-carotene, i.e. about $10 \%$. Bacterial carotenoids were recovered in significant amounts in their native chemical forms in plasma, liver and in adipose tissue of rats, which were force-fed for 3 days with either bacterial carotenoid extracts or lyophilised bacteria. Bacterial carotenoids were found at higher concentrations in rat tissues than $\beta$-carotene, about 2-3 times for GB1 carotenoids and 9 times for HU36 carotenoids. They were also more recovered in adipose tissue than $\beta$-carotene. In conclusion, glycosyl carotenoids from the HU36 and GB1 Bacillus strains are readily bioavailable. This is due in part to their higher bioaccessibility but perhaps also to their easier accumulation in tissues.

56

57 KEYWORDS: bacteria, $\beta$-carotene, micelles, absorption, bioavailability, probiotic. 


\section{INTRODUCTION}

60

Carotenoids are lipophilic dietary microconstituents that are not biosynthesized by humans but may have interesting beneficial properties for human health. Epidemiological studies have associated the consumption of carotenoid-rich foods (especially fruit and vegetables) with reduced risks of several diseases: e.g. age-related macular degeneration, some cancers, cardiovascular disease (Krinsky and Johnson, 2005; Stahl and Sies, 2005; Tapiero, Townsend, \& Tew, 2004). The beneficial effect of carotenoids on health was initially assumed to be mediated by their antioxidant activity (Tyssandier et al., 2004). However recent findings suggest that other mechanisms could be implicated such as effects on signalling pathways or on gene expression (Gouranton et al., 2011).

The potential health-promoting properties of carotenoids have led to substantial interest in carotenoids as nutritional supplements, especially from natural sources. $\beta$-Carotene is one of the naturally occurring carotenoid that have been most intensively studied. It can be used as a food colouring agent, as a dietary source of vitamin A (Krinsky and Johnson, 2005) and for other bioactive properties (Britton, Liaaen-Jensen, \& Pfander, 2008; Peto, Doll, Buckley, \& Sporn, 1981). Besides, bacterial producing carotenoids have gained interest in the past years due to their ability to act as probiotics (Hempel et al., 2012; Ma, Choi, Choi, Pothoulakis, Rhee, \& Im, 2010) and their potential to provide a suitable biosource of carotenoids with both $\mathrm{C} 40$ and C30 backbones (Perez-Fons et al., 2010) and with improved solubility and stability for the food and feed industry (Duc, Fraser, Tam, \& Cutting, 2006). A diverse range of spore-forming Bacillus species has been isolated that contain various red, pink or yellow-orange carotenoid pigments. Among Bacillus sp., the B. indicus HU36 and B. firmus GB1 strains are of particular interest for their high production of carotenoids, the resistance of their spores to UV radiations (Khaneja et al., 2010) and their amenable probiotic 
properties (Hong, Huang, Khaneja, Hiep, Urdaci, \& Cutting, 2008). The HU36 strain, which has been isolated in human faeces, synthesizes yellow-orange pigments in variable proportions depending on whether they are in the vegetative or spore-forming state. The corresponding carotenoid extract displays maxima of visible absorption at 429, 454 and 485 nm (Khaneja et al., 2010). The most abundant pigments in the extract were determined as 1glycosyl-3-4-dehydro-8'-apolycopene and methyl-1-glycosyl-3-4-dehydro-8'-apolycopenoate esters with saturated fatty acid secondary chains from C8 to C15 (Fig. 1 A) (Perez-Fons et al., 2010). The GB1 strain, which has been isolated from human ileum, produces deep-pink pigments with maxima of visible absorption at 463, 492 and $524 \mathrm{~nm}$ (Khaneja et al., 2010), the main one being 4,4'-diglycosyl-4,4'-diapolycopenoic diester (Fig. 1 B).

Knowledge on the metabolism of carotenoids in humans has been considerably increasing during the last ten years. It is now assumed that carotenoids have to be extracted from their vegetable matrix to be transferred into mixed micelles and efficiently absorbed. The efficiency of this transfer is called "bioaccessibility". Several factors have been identified that affect carotenoid bioaccessibility (Borel, 2003; West and Castenmiller, 1998). Among these factors we have recently shown (Sy, Gleize, Dangles, Landrier, Caris-Veyrat, \& Borel, 2012) that the chemical structure of carotenoids is a key-factor that modulates their solubility into mixed micelles. It has also been shown that the matrix in which carotenoids are embedded can play a significant role on bioaccessibility (Gartner, Stahl, \& Sies, 1997; Reboul et al., 2005b; Stahl and Sies, 1992; Sy et al., 2012). After being incorporated into mixed micelles, carotenoids are transported to the enterocyte, where they are absorbed via membrane transporters (Reboul and Borel, 2011). It is not yet known how these transporters facilitate the uptake of carotenoids and it has been hypothesized that carotenoid chemical structure might play a role in the interaction between carotenoid and their transporters. 
109 spores have raised question on their bioavailability, i.e. on the fraction of the dose which is

110 entering the systemic circulation to exert its function (or used for storage for later use). It was

111 indeed not known whether they efficiently solubilized into mixed micelles, whether they can

112 be absorbed by intestinal cells and whether they are transported within the body to reach the

113 main storage tissues of carotenoids, i.e. the liver and adipose tissue.

114 The aim of this study was therefore to compare the bioaccessibility, the uptake by

115 intestinal cell, and the tissue distribution of HU36 and GB1 carotenoids, with the most studied 116 carotenoid: $\beta$-carotene. 


\section{MATERIAL AND METHODS}

\subsection{Supplies and chemicals.}

121 Canned steamed carrots (Daucy, Vannes, France) were purchased from a local supermarket

122 and chosen without antioxidants, acidifiers or preservatives. Plain yogurt was from Danone

123 (Paris, France). Mixtures of lyophilized spores and vegetative cells from Bacillus strains

124 (HU36 and GB1) were provided by Paul Fraser and Reena Khaneja (Royal Holloway

125 University of London) in the frame of the COLORSPORE project (European Small

126 Collaborative Project No. 207948, FP7) (Duc et al., 2006). Carotenoids in bacterial extracts

127 were purified by liquid chromatography before the study and a purity $>90 \%$ was obtained.

128 Pure all-E $\beta$-carotene (> 95\%) was kindly provided by DSM LTD (Basel, Switzerland). Salts

$129\left(\mathrm{NaHCO}_{3}, \mathrm{NaCl}, \mathrm{KCl}, \mathrm{CaCl}_{2}, 2 \mathrm{H}_{2} \mathrm{O}\right.$ and $\left.\mathrm{K}_{2} \mathrm{HPO}_{4}\right)$, mucin, $\alpha$-amylase, pepsin, porcine

130 pancreatin, porcine bile extract, 2-Oleoyl-1-palmitoyl-sn-glycero-3-phosphocholine

131 (phosphatidylcholine), 1-palmitoyl-sn-glycero-3-phosphocholine (lysophosphatidylcholine),

132 monoolein, free cholesterol, oleic acid, sodium taurocholate, pyrogallol (used as antioxidant

133 preservative) and apo- 8 '-carotenal (> 95\%, used as internal standard to calculate recovery

134 yield during carotenoid extraction (Sy et al., 2012)) were purchased from Sigma-Aldrich (St

135 Quentin-Fallavier, France). FBS (foetal bovine serum) was purchased from Biomedia (Issy-

136 les-Moulineaux, France). DMEM (Dulbecco's Modified Eagle Medium) containing 4.5 g/L

137 glucose and trypsin/EDTA (500 and $200 \mathrm{mg} / \mathrm{L}$ respectively), non-essential amino acids,

138 penicillin/streptomycin, PBS (phosphate buffered saline solution) and PBS containing 0.1

$139 \mathrm{mmol} / \mathrm{L} \mathrm{CaCl}_{2}$ and $1 \mathrm{mmol} / \mathrm{L} \mathrm{MgCl}_{2}(\mathrm{PBSCM})$ were from Invitrogen (Cergy-Pontoise,

140 France). Hexane, methanol, dichloromethane and methyl-t-butylether (MTBE) were of HPLC

141 grade and purchased from Carlo Erba Reactifs SDS (Val-de-Reuil, France). The small kit of 
142 the Uptima bicinchoninic acid (BCA) assay for protein quantification was from Interchim

143 (Montluçon, France).

\subsection{Test meals used in the in vitro digestion experiments performed for assessing}

carotenoid bioaccessibility.

Experiments were performed twice for each carotenoid (or carotenoid mixture); first using pure solid $\beta$-carotene and purified bacterial extracts, in order to measure the intrinsic bioaccessibility of bacterial carotenoids (i.e. without the effect of the food matrix), then with foods rich in the studied carotenoids, in order to measure the bioaccessibility of bacterial carotenoids when they are digested in their usual matrix, i.e. bacteria. For experiments with

152 pure carotenoids, stock solutions of carotenoids in hexane were dispersed in commercial

153 groundnut oil, which did not contain quantifiable amounts of carotenoids as checked by

154 HPLC, and the solvent evaporated to obtain carotenoid concentrations of ca. $750 \mu \mathrm{mol} / \mathrm{L}$ in oil. The first digestions were conducted on the oil alone, while for experiments with foods, the food sources of carotenoids were codigested with a standard meal (Table 1). This was done in

157 order to be in nutritional conditions where carotenoid sources are usually ingested together

158 with other foods. Foods were chosen in order that i) they did not contained detectable amount

159 of carotenoids (checked by HPLC), and ii) their mix gave a meal composition in

160 macronutrients (lipids, carbohydrates and proteins) that was close to US-dietary

161 recommended intake in macronutrients (see table 1 legend). Potatoes were boiled in tap water,

162 peeled, and hand-pureed. Meat was fried in a frying-pan without added fat. Potato purée and

163 fried meat were divided into aliquots and frozen at $-20^{\circ} \mathrm{C}$. The food source of $\beta$-carotene was

164 commercial carrot purée. Lyophilized HU36 and GB1 cells + spores were homogenized in 165 plain yogurts (Table 2). 
reduce as much as possible the amount of triglycerides left at the end of the digestion experiments (Sy et al., 2012). Meal components, or only groundnut oil when the bioaccessibility of carotenoids was studied without the effect of the food matrix (Table 1), were mixed with $32 \mathrm{~mL} \mathrm{NaCl} 0.9 \%$ and homogenized in a shaking water bath at $37^{\circ} \mathrm{C}$ for 10 min. The next steps of the in vitro digestion procedure are described in detail in a recent publication of our team (Sy et al., 2012). Each experiment was run in triplicate.

Natural mixed micelles produced during in vitro digestion were separated as described recently (Sy et al., 2012).

\subsection{Monitoring of the bacterial material during in vitro digestion.}

Aliquots $(250 \mu \mathrm{L})$ were taken into the digestion medium at regular time intervals, i.e. $\mathrm{t}=0$ min (bacteria just added into the test meal), $\mathrm{t}=10 \mathrm{~min}$ (after addition of artificial saliva), $\mathrm{t}$ $=70 \mathrm{~min}$ (the end of gastric digestion), $\mathrm{t}=130 \mathrm{~min}$ (mid-term of duodenal digestion), and $\mathrm{t}=$ 190 min (the end of duodenal digestion). Samples were serially diluted in sodium phosphate buffer (0.2 M, pH 7.0) and $100 \mu \mathrm{L}$ were manually spread on Luria-Bertani (LB) agar (SigmaAldric, Steinheim, Germany) plates in duplicate. After 24 and $48 \mathrm{~h}$ incubation at $37^{\circ} \mathrm{C}$, concentrations of total bacterial population were expressed as colony forming units per millilitre (CFU/mL). The limit of detection was taken as one colony on the lowest dilution plate, i.e. $10 \mathrm{CFU} / \mathrm{mL}$. To determine spore concentrations, the samples were additionally heated at $75^{\circ} \mathrm{C}$ for $10 \mathrm{~min}$ previously to serial dilution in phosphate buffer and duplicate 
192

193

spreading on LB agar plates. In a separate test, the tolerance of HU36 and GB1 spores to porcine bile was estimated by following changes in bacterial counts in gastric media containing concentrations of porcine bile ranging from $8.09 \mathrm{~g} / \mathrm{L}$ to $80.90 \mathrm{mg} / \mathrm{L}$ (a control did not contain bile salts). After $48 \mathrm{~h}$ incubation at $37^{\circ} \mathrm{C}$, spore concentrations were expressed as $\mathrm{CFU} / \mathrm{mL}$. The limit of detection was taken as one colony on the lowest dilution plate, i.e. 10 $\mathrm{CFU} / \mathrm{mL}$.

\subsection{Determination of the intrinsic ability of bacterial carotenoids to be} incorporated into synthetic mixed micelles.

Synthetic mixed micelles either free of carotenoids or containing either pure $\beta$ carotene or bacterial carotenoids were prepared as previously described (Reboul et al., 2005a; Sy et al., 2012). Synthetic mixed micelle sizes were checked by photon correlation spectroscopy (Zetasizer Nano Zs, Malvern Instruments, Malvern, UK) (Sy et al., 2012).

The maximal amount of either $\beta$-carotene or purified bacterial carotenoids that can be incorporated into a fixed amount of synthetic mixed micelles was measured as previously described (Sy et al., 2012).

To measure the transfer of either $\beta$-carotene, or purified bacterial carotenoids, from their solid form into synthetic mixed micelles solubilised in water we used a protocol described in detail in a recent publication (Sy et al., 2012).

\subsection{In vitro carotenoid uptake by Caco-2 cell monolayers.}

Caco-2 clone TC-7 cells, which were a gift from Dr M. Rousset (UMR S872, Paris, France), were grown as recently described (Sy et al., 2012). Carotenoid uptake experiments were also described in detail in this publication (Sy et al., 2012). In summary the apical side of the cell monolayers received $1 \mathrm{~mL}$ carotenoid-rich natural mixed micelles, i.e. mixed micelles coming 
217 from the in vitro digestion of test-meals containing the food sources of carotenoids (i.e. carrot

218 puree or yogurt enriched in bacterial lyophilised material). Cell monolayers were incubated at

$21937^{\circ} \mathrm{C}$ for $3 \mathrm{~h}$. After the incubation period, media from each side of the membrane were

220 harvested. Cell monolayers were washed twice with $1 \mathrm{~mL}$ PBS, scraped, and collected in 500

$221 \mu \mathrm{L}$ PBS. All the samples were stored at $-80^{\circ} \mathrm{C}$ under nitrogen until carotenoid extraction and

222 HPLC analysis.

223

224

\subsection{Measurement of carotenoid bioavailability in an animal model.}

The animal model to study carotenoid bioavailability was multiple-dose gavage experiment lasting 3 days in young male albino Wistar rats (Sy et al., 2012). Multiple gavages over 3 days were preferred to dietary supplementation for several weeks because: i) the amounts of bacterial carotenoids available were limited, ii) gavage allows a better control of the amounts of carotenoids ingested by the rats, and iii) gavage limits carotenoid oxidation that can occur in foods given to rats and stored at room temperature. Experiments were conducted according to animal ethics rules and were approved by the Aix-Marseille University experimental animal ethic committee. Besides, the innocuousness of the bacterial carotenoid extracts and of the bacterial strains producing the carotenoids were studied by other partners of the project (Hong et al., 2008). Six groups of 8 rats were included in the study: a control group was force-fed with $1 \mathrm{~mL}$ groundnut oil without carotenoids, three groups were force-fed with the same amount of oil-containing purified carotenoids, i.e. pure $\beta$-carotene, purified HU36 carotenoids, or purified GB1 carotenoids, two groups were forcefed with yoghurts containing either HU36 or GB1 lyophilised bacterias. The gavage protocol was described in detail recently (Sy et al., 2012). The doses of carotenoid sources incorporated in oil and yoghurts and given to the rats were chosen so as to bring $0.15 \mathrm{mg}$ carotenoid/kg/day (Sy et al., 2012), which correspond to $10.5 \mathrm{mg} / \mathrm{d}$ for a man of $70 \mathrm{~kg}$. This 
dose of carotenoid remains nutritional as it is close to the daily total carotenoid intake, which

243 is estimated at $14 \mathrm{mg} / \mathrm{d}$ in Europe (O'Neill et al., 2001). The last gavage experiment was

244 carried out on fasting rats (Sy et al., 2012). Rats were killed exactly $4 \mathrm{~h}$ later, i.e. at the time

245 of maximal concentration of carotenoids in blood (Mathews-Roth, Welankiwar, Sehgal,

246 Lausen, Russett, \& Krinsky, 1990). Blood and tissues samples (liver and adipose tissue) were

247 collected. The blood samples were collected in tubes with heparin and immediately

248 centrifuged in order to separate the plasma. All the plasma and tissue samples were

249 immediately plunged into liquid $\mathrm{N}_{2}$ and kept at $-80^{\circ} \mathrm{C}$ until carotenoid analysis.

\subsection{Extraction of carotenoids from the various in vitro and in vivo samples.}

The procedure was adapted to the diverse types of samples (digesta, micellar fractions,

253 Caco-2 experiments fractions, plasma, liver and adipose tissue samples) and described in 254 detail recently (Sy et al., 2012).

\subsection{HPLC analysis of the carotenoids.}

After evaporation to dryness, all dried extracts were dissolved in $200 \mu \mathrm{L}$ methanol$\mathrm{CH}_{2} \mathrm{Cl}_{2}(65: 35, \mathrm{v} / \mathrm{v})$. Carotenoids were quantified as recently described (Gleize, Steib, Andre, 259 \& Reboul, 2012; Sy et al., 2012) by reverse-phase HPLC on a Dionex system (equipped with 260 in line degasser, a P680 pump, a cooled automatic sample injector ASI-100 and a UV/visible 261 diode-array detector UVD340U, Dionex France, Voisins-le-Bretonneux, France). Carotenoids 262 and apo-8'-carotenal (used as internal standard to calculate recovery yield during carotenoid 263 extraction) were detected at their wavelength of maximal absorption ( $455 \mathrm{~nm}$ for $\beta$-carotene 264 and HU36 carotenoids and $495 \mathrm{~nm}$ for GB1 carotenoids). Bacterial carotenoids in micelles, 265 cells and tissue samples were identified and quantified by their HPLC chromatogram and UV266 visible spectrum (from 300 to $550 \mathrm{~nm}$ ) in comparison with the HPLC chromatograms and 
UV-visible spectrums of the purified molecules. Calibration curves were performed with the purified bacterial carotenoids. Quantification was performed using Dionex Chromeleon software (Dionex Chromatography Management system, version 6.80).

\subsection{Protein assay on the tissue samples from the in vivo study.}

This method was described in detail recently (Sy et al., 2012).

\subsection{Calculations and Statistics.}

The extinction coefficients of the purified carotenoid mixtures were calculated after dilution of the mixtures in dichloromethane and OD measurements at 455 and $495 \mathrm{~nm}$ for the HU36 and GB1 carotenoids, respectively. The values obtained were 165000 and 225300 L. $\mathrm{mol}^{-1} \cdot \mathrm{cm}^{-1}$. The estimated mw of the bacterial carotenoid mixtures were 750 and $784 \mathrm{~g} / \mathrm{mol}$ for the HU36 and GB1 carotenoids, respectively. Bioaccessibility was defined as the percentage of carotenoids recovered in the micellar fraction after in vitro digestion, in relation to the amount of carotenoids measured in the digestive medium just before addition of artificial saliva. The solubility of the carotenoids in synthetic mixed micelles was defined as the percentage of carotenoids recovered in the micellar fraction, in relation to the total carotenoids present in the medium. Uptake efficiency of the carotenoids was defined as the percentage of carotenoids recovered in scraped Caco- 2 cells, in relation to the amount of carotenoids initially added on the apical sides of the cell monolayers. All the in vitro experiments were run in triplicate. Results were expressed as means and standard deviations. Differences between means were assessed using ANOVA followed by the post-hoc TukeyKramer's test for parametric data (in vitro results). In the case of non-parametric data (in vivo results), they were assessed using the Kruskal-Wallis' test followed by the Mann-Whitney $U$ test when the Kruskal-Wallis test showed significant differences between groups. $P$ values 
292 under 0.05 were considered significant. Statistical comparisons were performed using

293 StatView software version 5.0 (SAS Institute Inc., Cary, NC).

294 


\section{RESULTS}

296

297

298

299

300

301

302

303

304

305

306

307

308

309

310

311

312

313

314

315

316

317

318

\subsection{Fate of HU36 and GB1 bacteria during digestion.}

Most bacteria were present as vegetative cells in the lyophilised bacterial mixture, with only around $1 \%$ bacteria as spores in both strain preparations. Initial concentrations of viable cells were about $8 \times 10^{6} \mathrm{cfu} / \mathrm{mg}$ lyophilised material for HU36 and $2 \times 10^{5} \mathrm{cfu} / \mathrm{mg}$ lyophilised material for GB1. Initial concentrations of spores were $8 \times 10^{3} \mathrm{cfu} / \mathrm{mg}$ lyophilised material for HU36 and $3 \times 10^{2} \mathrm{cfu} / \mathrm{mg}$ lyophilised material for GB1. The number of viable cells and spores decreased during the gastric digestion (Fig. 2B). During the duodenal digestion the number of GB1 cells continued to diminish in the first hour than remained stable during the second hour. The spore concentrations remained relatively unchanged (final spore populations were $8 \times 10^{4}$ cfu for HU36 and $1 \times 10^{4}$ cfu for GB1), showing in particular a rather low germination. Final vegetative cell populations were $9 \times 10^{7}$ cfu for HU36 and around $5 \times 10^{5}$ cfu for GB1 (i.e. $66 \%$ and $92 \%$ viability loss, respectively) (Fig. 2, A \& B). In conclusion, the bioaccessibility of carotenoids does not depend on cellular growth.

\subsection{Stability of bacterial carotenoids during digestion.}

HPLC chromatograms suggest that both yellow and orange HU36 glycosyl carotenoid esters were transformed during the in vitro digestion experiment (Fig. 3, B vs A). The digestion of GB1 carotenoids led to 2 new pigments (Fig. 4, B vs A), which were likely less hydrophobic (more polar) than the native carotenoids, i.e. because they eluted earlier. New products could result from autoxidation (oxidation by $\mathrm{O}_{2}$ initiated by metal traces) and/or (in the case of the bacterial carotenoids) hydrolysis of sugar and acyl moieties by the digestive enzymes. GB1 carotenoids were the most stable with $81.0 \pm 0.6 \%$ of area under the curves of 
the initial carotenoids recovered at the end of digestion. The residual amounts of $\beta$-carotene and native HU36 carotenoids were identical: $69.5 \pm 1.2 \%$ and $69.5 \pm 4.3 \%$ respectively.

\subsection{Bioaccessibility of bacterial carotenoids as measured by the in vitro digestion}

323

model.

Purified HU36 and GB1 carotenoids were equally bioaccessible with about $60 \%$ of the initial carotenoid content recovered in the micellar fraction. Pure $\beta$-carotene was about 5 times less bioaccessible (Fig. 5). Comparison of HPLC chromatograms of bacterial carotenoids recovered in the micellar fraction vs. those present in the whole medium at the end of the duodenal digestion, showed that the different carotenoids that were present in the bacterial carotenoid extract were incorporated into natural mixed micelles with similar efficiencies (data not shown).

As shown in Fig. 5, the carrot purée matrix had no significant effect on $\beta$-carotene bioaccessibility. Conversely, the bacterial matrices significantly diminished bacterial carotenoid bioaccessibility (by a factor ca. 2). Nevertheless note that the bioaccessibility of bacterial carotenoids contained in mixtures of cells and spores, was significantly higher than that of $\beta$-carotene, either digested pure or in carrot purée.

\subsection{Incorporation of purified bacterial carotenoids into synthetic mixed micelles.}

First of all we measured the solubility of purified bacterial carotenoids in water because we suspected that they are partially soluble in water due to their glycosid groups. The values measured were ca. 0.25 and $0.16 \mu \mathrm{mol} / \mathrm{L}$ for HU36 and GB1, respectively. These values are of course higher than that of $\beta$-carotene (essentially insoluble in water) but markedly lower than their solubility in synthetic micelles. Indeed, when homogenized with phospholipids, cholesterol and glycerol esters (mixed micelle lipids) before the formation of 
synthetic mixed micelles, incorporation efficiencies of purified HU36 carotenoids and GB1 carotenoids were over $90 \%$ (Table 3 ). This was significantly higher than that of pure $\beta$ carotene (about 50\%).

The percentage versus time of transfer of pure carotenoids from carotenoid powders to

348 pre-formed synthetic mixed micelles in water is shown in Fig. 6. In all cases, the maximal

349 solubilisation rates were nearly reached in the first 30 to $60 \mathrm{~min}$. The maximal transfer of

350 carotenoids measured at the plateau revealed that bacterial carotenoids were significantly

351 more transferred from powder into synthetic mixed micelles (over 70\%) than $\beta$-carotene

352 (around 8\%). Moreover, maximal percentage values of carotenoids transferred into synthetic

353 mixed micelles were significantly lower than in the incorporation of carotenoids during the

354 preparation of synthetic mixed micelles (Table 3).

\subsection{Uptake of carotenoids by Caco-2 cells.}

The Caco-2 cells monolayers were incubated with carotenoid-rich natural mixed micelles coming from the in vitro digestions of the test-meals containing the food sources of carotenoids (carrot purée or yoghurts enriched with lyophilised mixtures of vegetative cells + spores) and the uptake efficiencies of the carotenoids were compared. Note that no carotenoid was detected in the basolateral media. This was not surprising because it is well known that

362 Caco-2 hardly secrete lipoproteins which are the carrier of carotenoids in the basolateral 363 medium. Note also that the following $\beta$-carotene metabolites: retinol, and retinyl palmitate, 364 were not detected in the cells, suggesting that the incubation conditions did not allow $\beta, \beta-$ 365 carotene-15,15'-monooxygenase (Duszka, Grolier, Azim, Alexandre-Gouabau, Borel, \& 366 Azais-Braesco, 1996; Grolier, Duszka, Borel, Alexandre-Gouabau, \& Azais-Braesco, 1997;

367 Lobo, Amengual, Palczewski, Babino, \& von Lintig, 2012) to significantly cleave $\beta$-carotene.

368 Both HPLC chromatograms showed the presence of native bacterial carotenoids and $\beta$ - 
carotene in the Caco- 2 cell fractions. Uptake efficiency of $\beta$-carotene, HU36 carotenoids and GB1 carotenoids were not significantly different and fell in the range 6-11\% (Fig. 7).

To assess whether Caco-2 cell uptake was selective to some bacterial carotenoids, a complementary experiment was conducted with synthetic mixed micelles. Indeed, synthetic mixed micelles allowed incorporation of higher amounts of carotenoids, thus facilitating identification. After $3 \mathrm{~h}$ incubation, all the bacterial carotenoids apparently exhibited similar uptake efficiencies and did not undergo significant metabolism in Caco-2 cells. Indeed, HPLC profiles were similar in synthetic mixed micelles and in Caco-2 cells (data not shown).

\subsection{Blood and tissue bacterial carotenoid responses, i.e. changes from initial concentrations, to bacterial carotenoid gavages in rats.}

No carotenoids were detected either in rat plasma before the gavages or in plasma and tissues of rats that were force-feed with carotenoid-free oil (data not shown). In addition, retinyl palmitate concentrations, which can increase with provitamin A carotenoids, did not significantly vary in either plasma or liver, either before or after gavage with the studied carotenoid sources. Concentrations of carotenoids in plasma and tissues after 3-day gavage with carotenoids are shown in table 4. Note that, for an unknown reason, the variabilities of plasma and tissue concentrations of bacterial carotenoids were much higher than that $\beta$ carotene. However it appears that all plasma, liver and adipose tissue concentrations of bacterial carotenoids were higher than that of $\beta$-carotene.

Fig. 8 shows the total amounts and proportions of carotenoids recovered in plasma, liver and adipose tissue. The total amount of bacterial carotenoids recovered in plasma+liver+adipose tissue was significantly $(\mathrm{p}<0.05)$ higher after gavage with HU36 carotenoids (about 9 times as high) than with pure $\beta$-carotene. The total amount of GB1 carotenoids was about 2-3 times as high as $\beta$-carotene (not statistically significant likely 
394 because of the high variability in bacterial carotenoid response). Bacterial carotenoids were

395 recovered in higher proportion in the adipose tissue (8-43\%) than $\beta$-carotene (7\%).

396 


\section{DISCUSSION}

398

400

401

402

403

404

405

406

407

408

409

410

411

412

413

414

415

416

417

The objective of this study was to assess the bioavailability of glycosyl carotenoids and glycosyl carotenoid esters from HU36 and GB1 Bacillus sp. strains. To that purpose, complementary models were used to study the 3 key-steps that govern carotenoid bioavailability: i) bioaccessibility, which was quantifed in a standard in vitro digestion model (Fernández-García, Carvajal-Lérida, \& Pérez-Gálvez, 2009; Garrett et al., 1999; Reboul et al., 2006), ii) uptake efficiency by human intestinal cells, which was assessed by the widely used Caco-2 cell model (Artursson and Karlsson, 1991; During, Albaugh, \& Smith, 1998; Grès et al., 1998), iii) distribution in tissues, which was assessed by a home-made force-feeding model in rats with dietary doses of carotenoids (Sy et al., 2012). $\beta$-Carotene was selected as a reference carotenoid.

The first limiting-step for carotenoid bioavailability is assumed to be their transfer into mixed micelles in the duodenal lumen during digestion. Our results on the efficiency of transfer of purified carotenoids from carotenoid powders to synthetic mixed micelles in water (fig 6) clearly showed that HU36 and GB1 carotenoids were very efficiently incorporated into synthetic mixed micelles, in fact much better than $\beta$-carotene. This is perhaps due to their higher melting point brought about by their polar glycosyl moieties. Indeed, we have recently shown that the incorporation efficiency of carotenoids in synthetic micelles was related to carotenoid melting point (Sy et al., 2012). The very efficient transfer of bacterial carotenoids to mixed micelles likely explains the higher bioaccessibility of these carotenoids, as compared to $\beta$-carotene, in the in vitro digestion experiments (fig 5). Because bacterial carotenoids are most likely to be developed as dietary supplements under the form of bacteria (probiotics) (Hempel et al., 2012; Ma et al., 2010) it was interesting to compare the bioaccessibility of these carotenoids either when they are embedded in their natural matrix, i.e. spores and 
vegetative cells, or when they are extracted and purified. As expected, the bioaccessibility of the bacterial carotenoids from lyophilized cells was only ca. twice as low as from pure extracts. We hypothesize that this lower bioaccessibility was due to a less efficient release of carotenoids from spores or vegetative cells, due to the double coat of Bacillus cells (plasmic membrane + peptidoglycanes).

The second limiting-step for carotenoid bioavailability is assumed to be their absorption by the intestinal cell. The first significant result of the caco- 2 cell experiments was that native, i.e. esterified and glycosylated, bacterial carotenoids were found in Caco- 2 cell fractions, and thus assumed to be absorbed. This was surprising because most glycosides and esters of nutrients and micronutrients are hydrolyzed in the gastrointestinal tract lumen, and it is assumed that only the free forms of the nutrients and micronutrients are absorbed by the intestinal cell. Nevertheless this result is supported by the fact that native bacterial carotenoids were also recovered in blood and tissue of rats. It is not known whether the mechanism of uptake of bacterial carotenoids involves scavenger receptors, as reported for common carotenoids (Moussa et al., 2011; Moussa et al., 2008; Reboul et al., 2005a; Reboul and Borel, 2011), but the similar absorption efficiency observed herein between bacterial carotenoids and $\beta$-carotene suggests that similar mechanisms are involved. In fact this is in agreement with recent results showing that structural differences in carotenoids do not have a significant impact on the uptake efficiency of carotenoids in intestinal cells (Sy et al., 2012).

After absorption, carotenoids are mainly transported by the chylomicrons to the liver, then to other tissues by lipoproteins (Tyssandier, Choubert, Grolier, \& Borel, 2002). In the rat experiments, much higher amounts of bacterial carotenoids than $\beta$-carotene were recovered in the liver and in the adipose tissue. Because there was no significant conversion of carotenoids in vitamin $\mathrm{A}$ in this experiment (as suggested by the lack of significant increase in liver retinyl palmitate concentrations or plasma retinol concentrations following the $\beta$-carotene or 
447 bacterial carotenoid gavages), we conclude that HU36 carotenoids were about nine times as

448 bioavailable as $\beta$-carotene and that GB1 carotenoids were about two to three times as

449 bioavailable as $\beta$-carotene. Moreover, by comparing these results with results on the

450 bioavailability of other carotenoids, results obtained with the same protocol by our team (Sy

451 et al., 2012), we concluded that HU36 carotenoids are also more bioavailable than

452 astaxanthin, lutein and lycopene. The very high concentration of HU36 carotenoids in tissues,

453 as compared to $\beta$-carotene, can be explained by their higher bioaccessibility, but also by a

454 very inefficient degradation of these carotenoids in the body. Although we were not able to

455 verify this hypothesis with the model we used, this raises the question of the potential

456 accumulation of these carotenoids in the body and its physiological consequences. Additional

457 studies are therefore necessary to study the metabolism of these bacterial carotenoids in

458 tissues and the potential biological effects of their metabolites.

459

On the whole, this study suggests that bacterial carotenoids from the Bacillus HU36

461 and GB1 strains are more bioavailable than common carotenoids. This higher bioavailability

462 apparently reflects their very high bioaccessibility, which is likely due to the presence of

463 glycosyl groups that increase their micellar solubility. Finally, significant amount of bacterial

464 carotenoids were recovered under their native forms in liver and adipose tissue of rats. Thus,

465 their long-term tissue accumulation, metabolism and potential bioactivity and toxicity in

466 humans deserve additional investigations.

467 
468 5. AUTHORS' CONTRIBUTION TO THE ARTICLE

469

$470 \mathrm{~PB}$ and CS designed the protocol and have primary responsibility for the final content. CS

471 performed all the experiments with the help of BG, for the rat experiments, and of SC, for the

472 microbiology experiments. CS and PB drafted the manuscript. All authors contributed to the 473 final version of the manuscript. 


\section{REFERENCES}

Artursson, P., \& Karlsson, J. (1991). Correlation between oral drug absorption in humans and apparent drug permeability coefficients in human intestinal epithelial (Caco-2) cells. Biochemical and Biophysical Research Communications, 175, 880-885.

Borel, P. (2003). Factors affecting intestinal absorption of highly lipophilic food microconstituents (fat-soluble vitamins, carotenoids and phytosterols). Clinical Chemistry and Laboratory Medicine, 41, 979-994.

Britton, G., Liaaen-Jensen, S., \& Pfander, H. (2008). Special molecules, special properties. In G. Britton, S. Liaaen-Jensen \& H. Pfander (Eds.), Carotenoids. Volume 4: Natural functions (pp. 1-6). Basel Switzerland: Birkhauser Verlag AG.

Duc, L. H., Fraser, P. D., Tam, N. K. M., \& Cutting, S. M. (2006). Carotenoids present in halotolerant Bacillus spore formers. Fems Microbiology Letters, 255, 215-224.

During, A., Albaugh, G., \& Smith, J. C. (1998). Characterization of [beta]-carotene 15,15'dioxygenase activity in TC7 clone of human intestinal cell line Caco-2. Biochemical and Biophysical Research Communications, 249, 467-474.

Duszka, C., Grolier, P., Azim, E. M., Alexandre-Gouabau, M. C., Borel, P., \& Azais-Braesco, V. (1996). Rat intestinal beta-carotene dioxygenase activity is located primarily in the cytosol of mature jejunal enterocytes. Journal of Nutrition, 126, 2550-2556.

Fernández-García, E., Carvajal-Lérida, I., \& Pérez-Gálvez, A. (2009). In vitro bioaccessibility assessment as a prediction tool of nutritional efficiency. Nutrition Research, 29, 751760.

Garrett, D. A., Failla, M. L., \& Sarama, R. J. (1999). Development of an in vitro digestion method to assess carotenoid bioavailability from meals. Journal of Agricultural and Food Chemistry, 47, 4301-4309. 
Gartner, C., Stahl, W., \& Sies, H. (1997). Lycopene is more bioavailable from tomato paste than from fresh tomatoes. American Journal of Clinical Nutrition, 66, 116-122.

Gleize, B., Steib, M., Andre, M., \& Reboul, E. (2012). Simple and fast HPLC method for simultaneous determination of retinol, tocopherols, coenzyme Q10 and carotenoids in complex samples Food Chemistry. Food Chemistry, 134, 2560-2564.

Gouranton, E., Thabuis, C., Riollet, C., Malezet-Desmoulins, C., El Yazidi, C., Amiot, M. J., et al. (2011). Lycopene inhibits proinflammatory cytokine and chemokine expression in adipose tissue. Journal of Nutritional Biochemistry, 22, 642-648.

Grès, M.-C., Julian, B., Bourrié, M., Meunier, V., Roques, C., Berger, M., et al. (1998). Correlation between oral drug absorption in humans, and apparent drug permeability in TC-7 cells, a human epithelial intestinal cell line: Comparison with the parental Caco-2 cell line. Pharmaceutical Research, 15, 726-733.

Grolier, P., Duszka, C., Borel, P., Alexandre-Gouabau, M. C., \& Azais-Braesco, V. (1997). In vitro and in vivo inhibition of beta-carotene dioxygenase activity by canthaxanthin in rat intestine. Archives of Biochemistry and Biophysics, 348, 233-238.

Hempel, S., Newberry, S. J., Maher, A. R., Wang, Z., Miles, J. N., Shanman, R., et al. (2012). Probiotics for the prevention and treatment of antibiotic-associated diarrhea: a systematic review and meta-analysis. The Journal of the American Medical Association, 307, 1959-1969.

Hong, H. A., Huang, J. M., Khaneja, R., Hiep, L. V., Urdaci, M. C., \& Cutting, S. M. (2008). The safety of Bacillus subtilis and Bacillus indicus as food probiotics. Journal of Applied Microbiology, 105, 510-520.

Khaneja, R., Perez-Fons, L., Fakhry, S., Baccigalupi, L., Steiger, S., To, E., et al. (2010). Carotenoids found in Bacillus. Journal of Applied Microbiology, 108, 1889-1902. 
Krinsky, N. I., \& Johnson, E. J. (2005). Carotenoid actions and their relation to health and disease. Molecular Aspects of Medicine, 26, 459-516.

Lobo, G. P., Amengual, J., Palczewski, G., Babino, D., \& von Lintig, J. (2012). Carotenoidoxygenases: Key players for carotenoid function and homeostasis in mammalian biology. Biochimica et Biophysica Acta (BBA) - Molecular and Cell Biology of Lipids, $1821,78-87$.

Ma, E. L., Choi, Y. J., Choi, J., Pothoulakis, C., Rhee, S. H., \& Im, E. (2010). The anticancer effect of probiotic Bacillus polyfermenticus on human colon cancer cells is mediated through ErbB2 and ErbB3 inhibition. International Journal of Cancer, 127, 780-790.

Mathews-Roth, M. M., Welankiwar, S., Sehgal, P. K., Lausen, N. C., Russett, M., \& Krinsky, N. I. (1990). Distribution of [14C]canthaxanthin and [14C]lycopene in rats and monkeys. Journal of Nutrition, 120, 1205-1213.

Moussa, M., Gouranton, E., Gleize, B., Yazidi, C. E., Niot, I., Besnard, P., et al. (2011). CD36 is involved in lycopene and lutein uptake by adipocytes and adipose tissue cultures. Molecular Nutrition \& Food Research, 55, 578-584.

Moussa, M., Landrier, J. F., Reboul, E., Ghiringhelli, O., Comera, C., Collet, X., et al. (2008). Lycopene absorption in human intestinal cells and in mice involves scavenger receptor class B type I but not Niemann-Pick C1-like 1. Journal of Nutrition, 138, 1432-1436.

O'Neill, M. E., Carroll, Y., Corridan, B., Olmedilla, B., Granado, F., Blanco, I., et al. (2001). A European carotenoid database to assess carotenoid intakes and its use in a fivecountry comparative study. British Journal of Nutrition, 85, 499-507.

Perez-Fons, L., Steiger, S., Khaneja, R., Bramley, P. M., Cutting, S. M., Sandmann, G., et al. (2010). Identification and the developmental formation of carotenoid pigments in the yellow/orange Bacillus spore-formers. Biochimica et Biophysica Acta (BBA) Molecular and Cell Biology of Lipids, 1811, 177-185. 
Peto, R., Doll, R., Buckley, J. D., \& Sporn, M. B. (1981). Can dietary beta-carotene materially reduce human cancer rates. Nature, 290, 201-208.

Reboul, E., Abou, L., Mikail, C., Ghiringhelli, O., Andre, M., Portugal, H., et al. (2005a). Lutein transport by Caco-2 TC-7 cells occurs partly by a facilitated process involving the scavenger receptor class B type I (SR-BI). Biochemical Journal, 387, 455-461.

Reboul, E., \& Borel, P. (2011). Proteins involved in uptake, intracellular transport and basolateral secretion of fat-soluble vitamins and carotenoids by mammalian enterocytes. Progress in Lipid Research, 50, 388-402.

Reboul, E., Borel, P., Mikail, C., Abou, L., Charbonnier, M., Caris-Veyrat, C., et al. (2005b). Enrichment of tomato paste with $6 \%$ tomato peel increases lycopene and beta-carotene bioavailability in men. Journal of Nutrition, 135, 790-794.

Reboul, E., Richelle, M., Perrot, E., Desmoulins-Malezet, C., Pirisi, V., \& Borel, P. (2006). Bioaccessibility of carotenoids and vitamin E from their main dietary sources. Journal of Agricultural and Food Chemistry, 54, 8749-8755.

Stahl, W., \& Sies, H. (1992). Uptake of lycopene and its geometrical isomers is greater from heat-processed than from unprocessed tomato juice in humans. Journal of Nutrition, $122,2161-2166$.

Stahl, W., \& Sies, H. (2005). Bioactivity and protective effects of natural carotenoids. Biochimica et Biophysica Acta (BBA) - Molecular Basis of Disease, 1740, 101-107.

Sy, C., Gleize, B., Dangles, O., Landrier, J. F., Caris-Veyrat, C., \& Borel, P. (2012). Effects of physicochemical properties of carotenoids on their bioaccessibility, intestinal cell uptake, and blood and tissue concentrations. Molecular Nutrition \& Food Research, $56,1385-1397$.

Tapiero, H., Townsend, D. M., \& Tew, K. D. (2004). The role of carotenoids in the prevention of human pathologies. Biomedicine \& Pharmacotherapy, 58, 100-110. 
Tyssandier, V., Choubert, G., Grolier, P., \& Borel, P. (2002). Carotenoids, mostly the xanthophylls, exchange between plasma lipoproteins. International Journal for Vitamin and Nutrition Research, 72, 300-308.

Tyssandier, V., Feillet-Coudray, C., Caris-Veyrat, C., Guilland, J. C., Coudray, C., Bureau, S., et al. (2004). Effect of tomato product consumption on the plasma status of antioxidant microconstituents and on the plasma total antioxidant capacity in healthy subjects. Journal of the American College of Nutrition, 23, 148-156.

Tyssandier, V., Reboul, E., Dumas, J. F., Bougteloup-Demange, C., Armand, M., Marcand, J., et al. (2003). Processing of vegetable-borne carotenoids in the human stomach and duodenum. American Journal of Physiology - Gastrointestinal and Liver Physiology, 284, G913-G923.

West, C. E., \& Castenmiller, J. J. J. M. (1998). Quantification of the "SLAMENGHI" factors for carotenoid bioavailability and bioconversion. International Journal for Vitamin and Nutrition Research, 68, 371-377. 


\section{FIGURES}

A

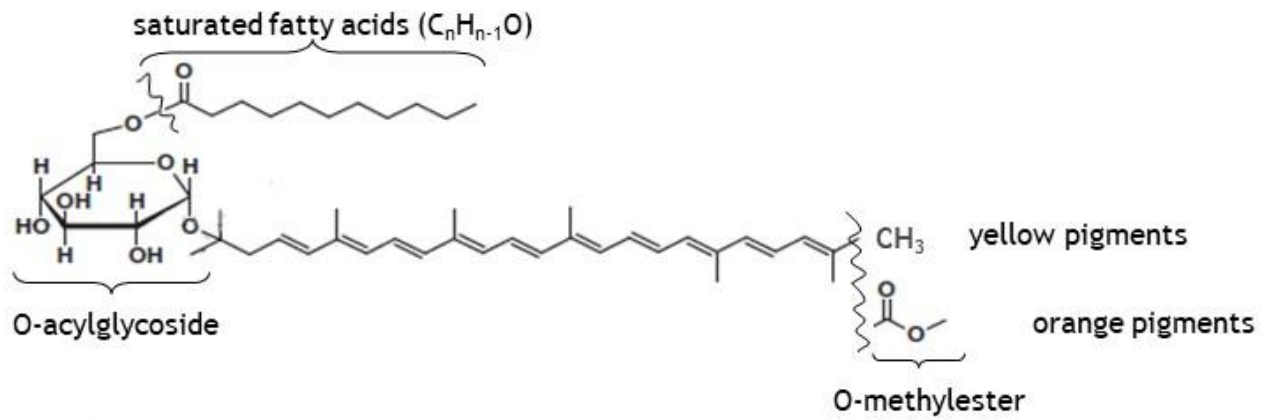

B

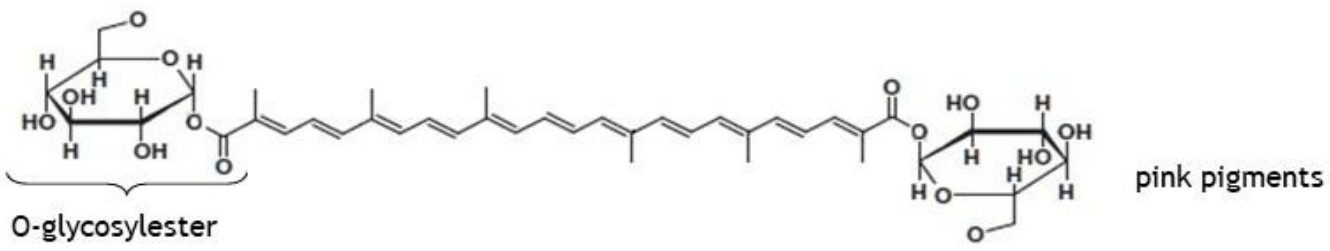

Figure 1: Chemical structures of the main carotenoids synthesised by (A) HU36 and (B) GB1 spore-forming strains. 

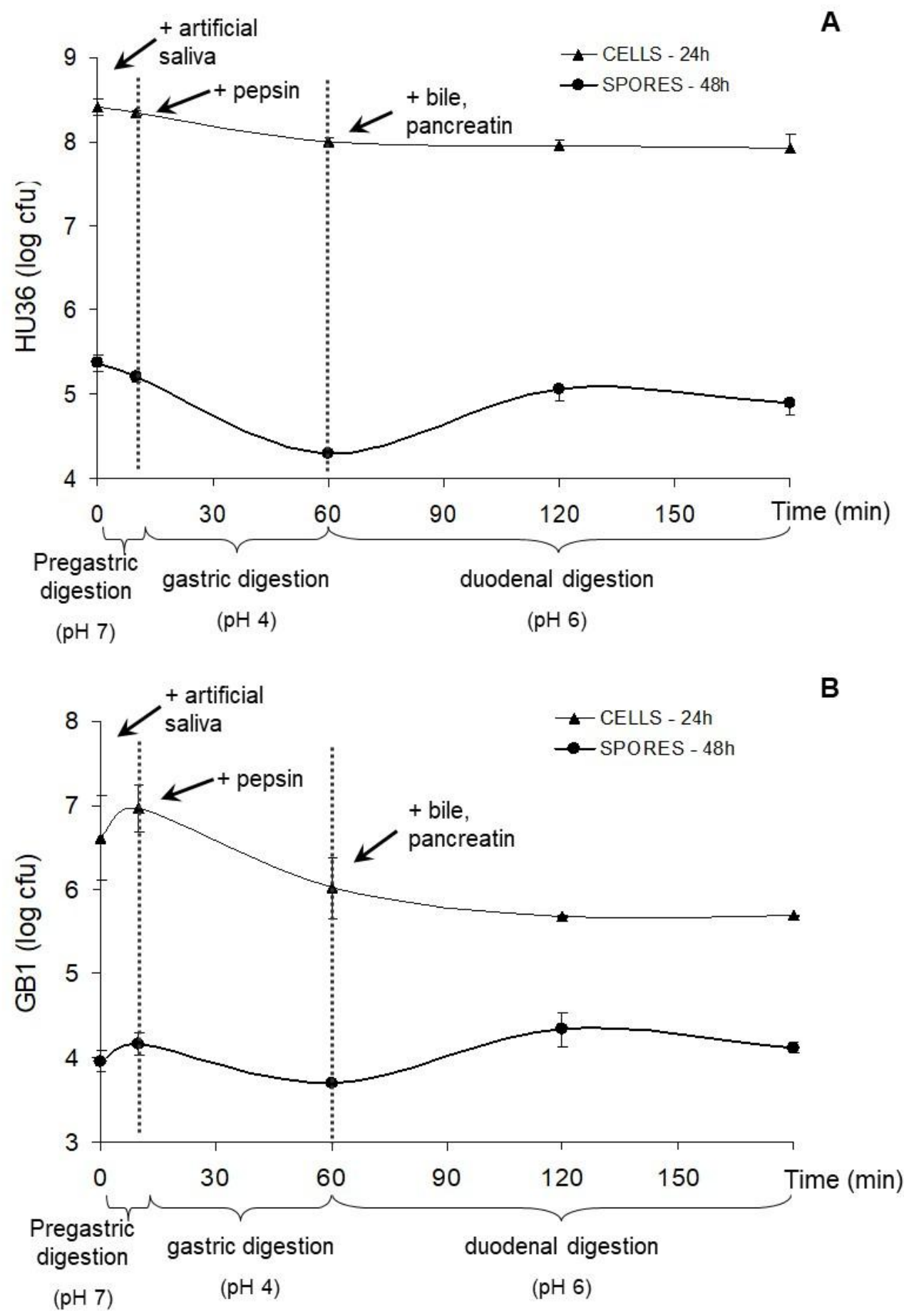

Figure 2: Evolution of the number of vegetative bacterial cells and of spores during in vitro digestion conducted with $32 \mathrm{mg}$ lyophilized bacterial material of (A) HU36 and (B) GB1 strains. Means \pm SD of three independent experiments. For more details see the material and methods section. 


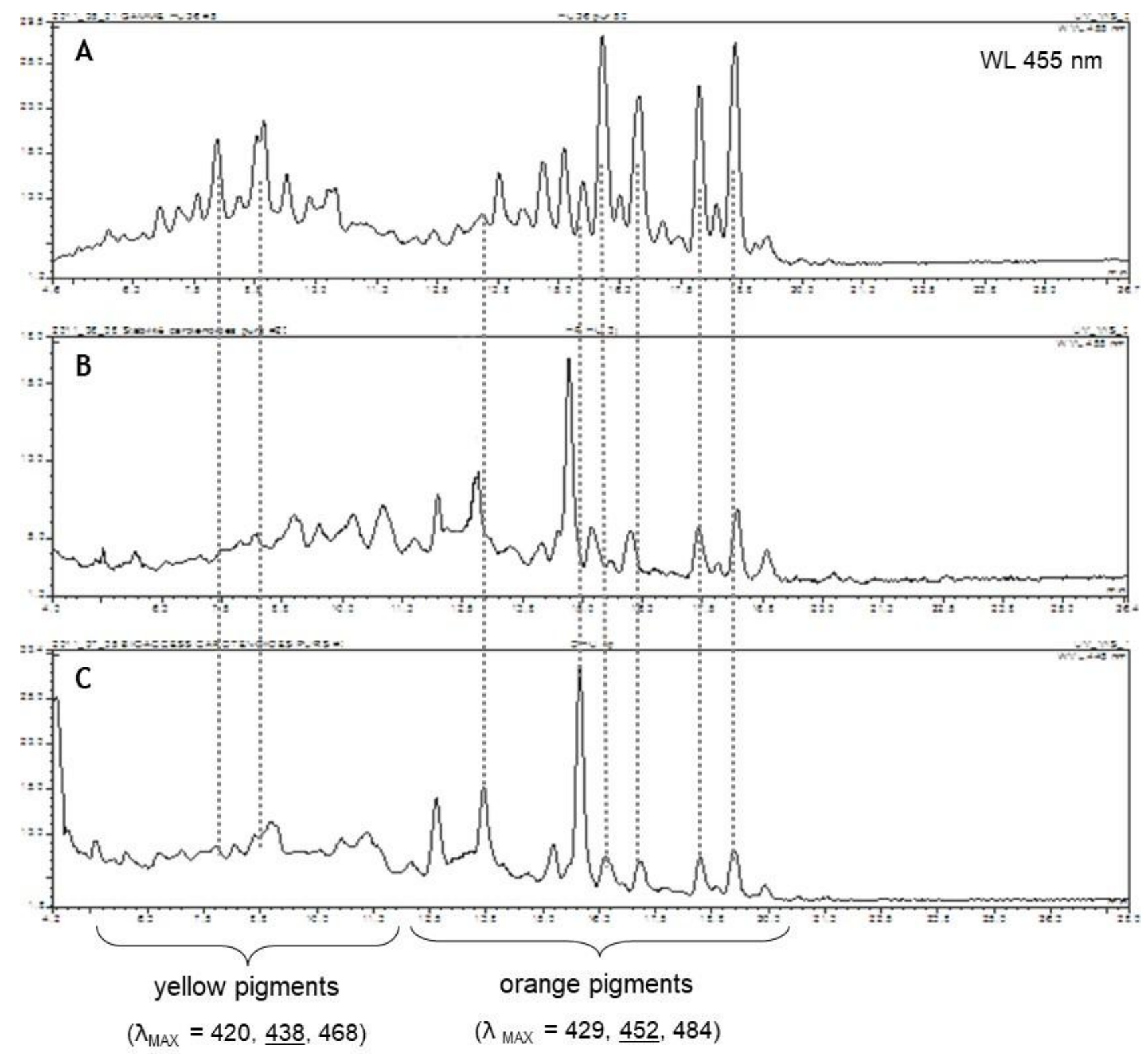

Figure 3: HPLC chromatograms with detection at $455 \mathrm{~nm}$ showing HU36 carotenoids in samples of (A) food mixture before in vitro digestion, (B) digestive medium at the end of the in vitro digestion, and (C) mixed micelle fraction at the end of the in vitro digestion. Dotted lines indicate similar compounds as suggested by their similar UV-visible spectra. 


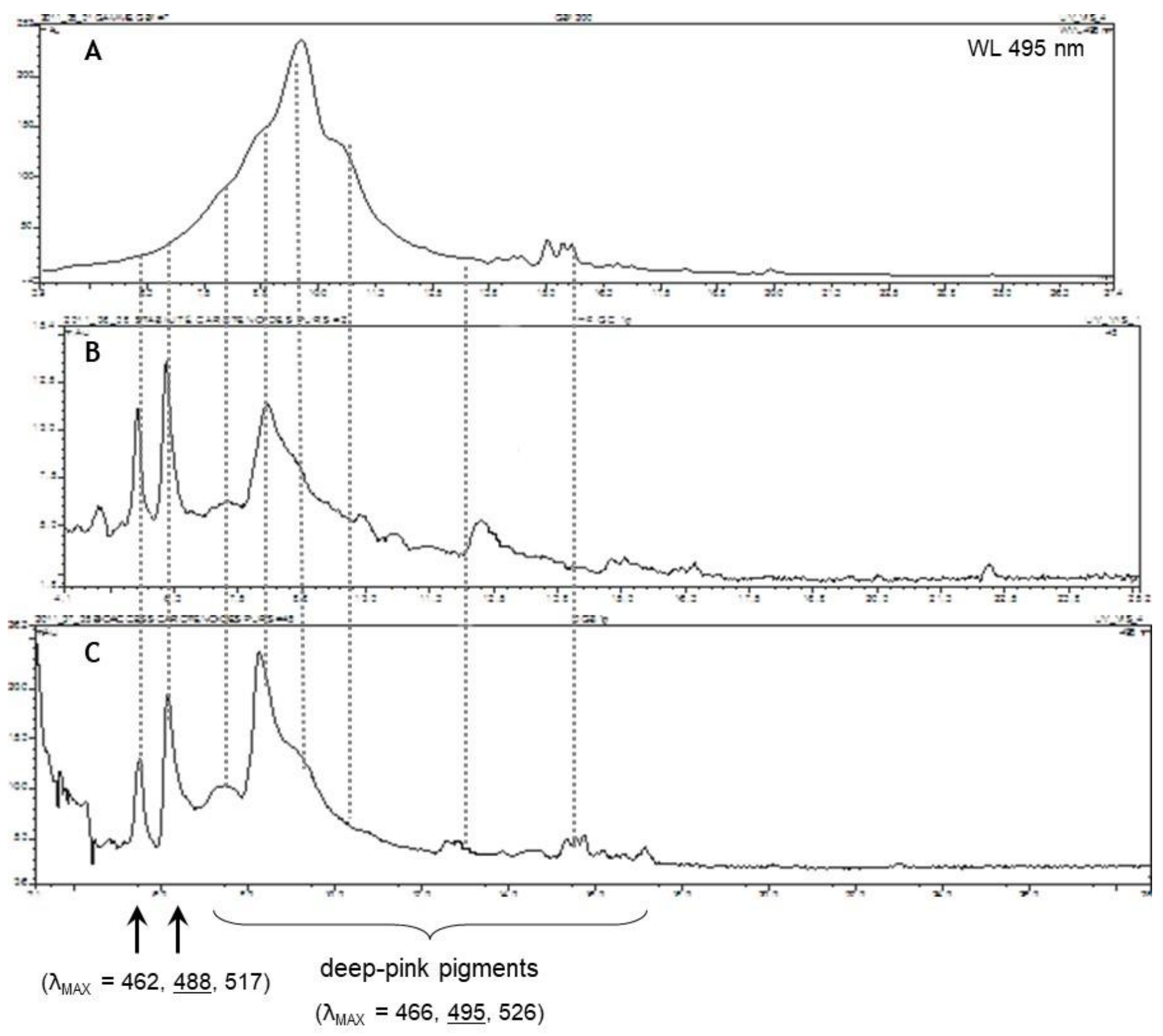

Figure 4: HPLC chromatograms with detection at $495 \mathrm{~nm}$ showing GB1 carotenoids in samples of (A) food mixture before in vitro digestion, (B) digestive medium at the end of the in vitro digestion, and $(\mathbf{C})$ mixed micelle fraction at the end of the in vitro digestion. Dotted lines indicate similar compounds as suggested by their similar UV-visible spectra. Arrows show pigments that appeared at the end of the in vitro digestion. 


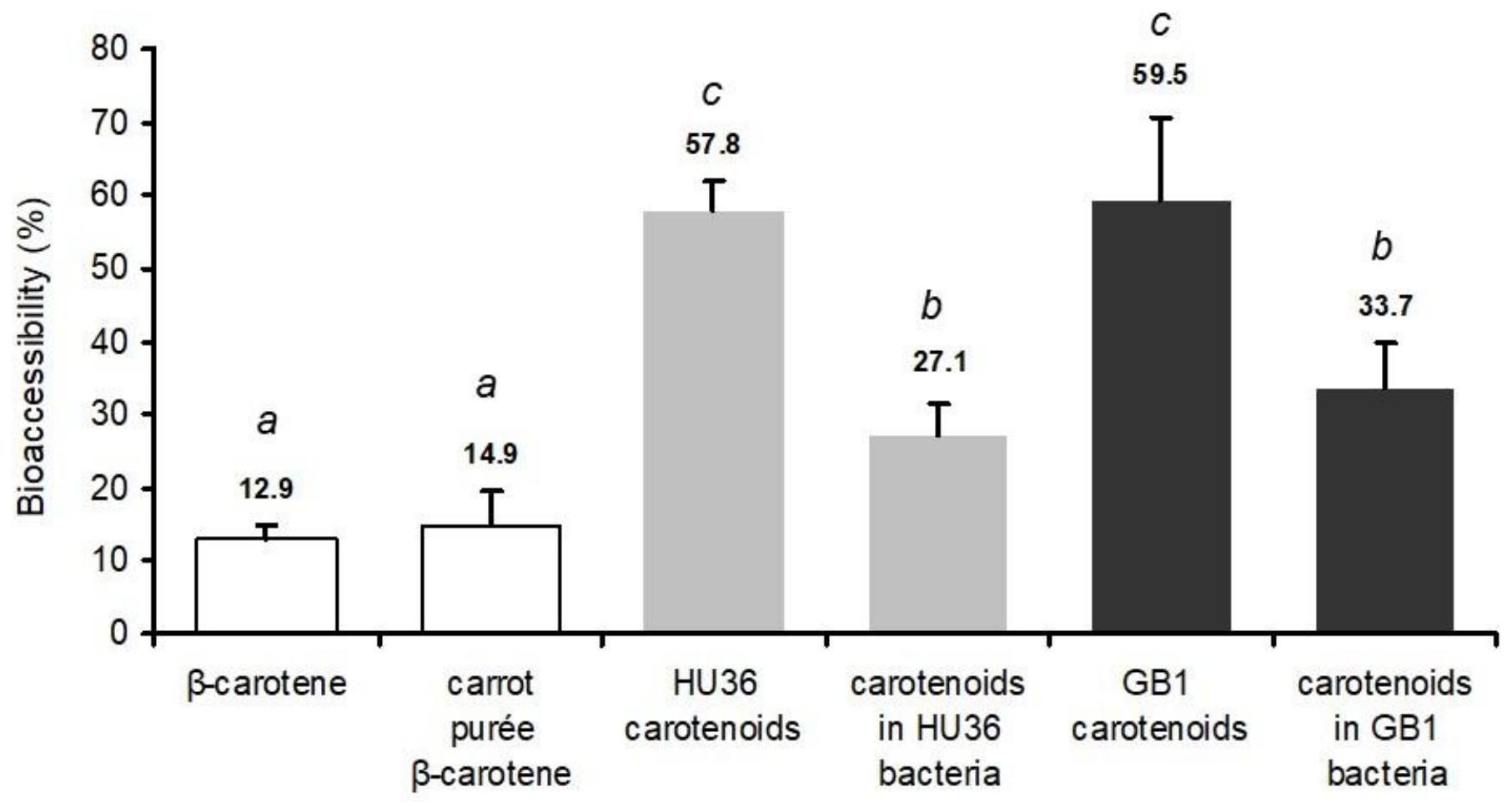

Figure 5: Bioaccessibility of $\beta$-carotene and bacterial carotenoids, either incorporated as pure molecules in oil or provided in their natural food matrix (carrot purée and bacteria), measured using the in vitro digestion model. Means \pm SD of three independent experiments. Different letters indicate significant $(P<0.05)$ differences between means (ANOVA and TukeyKramer test). 


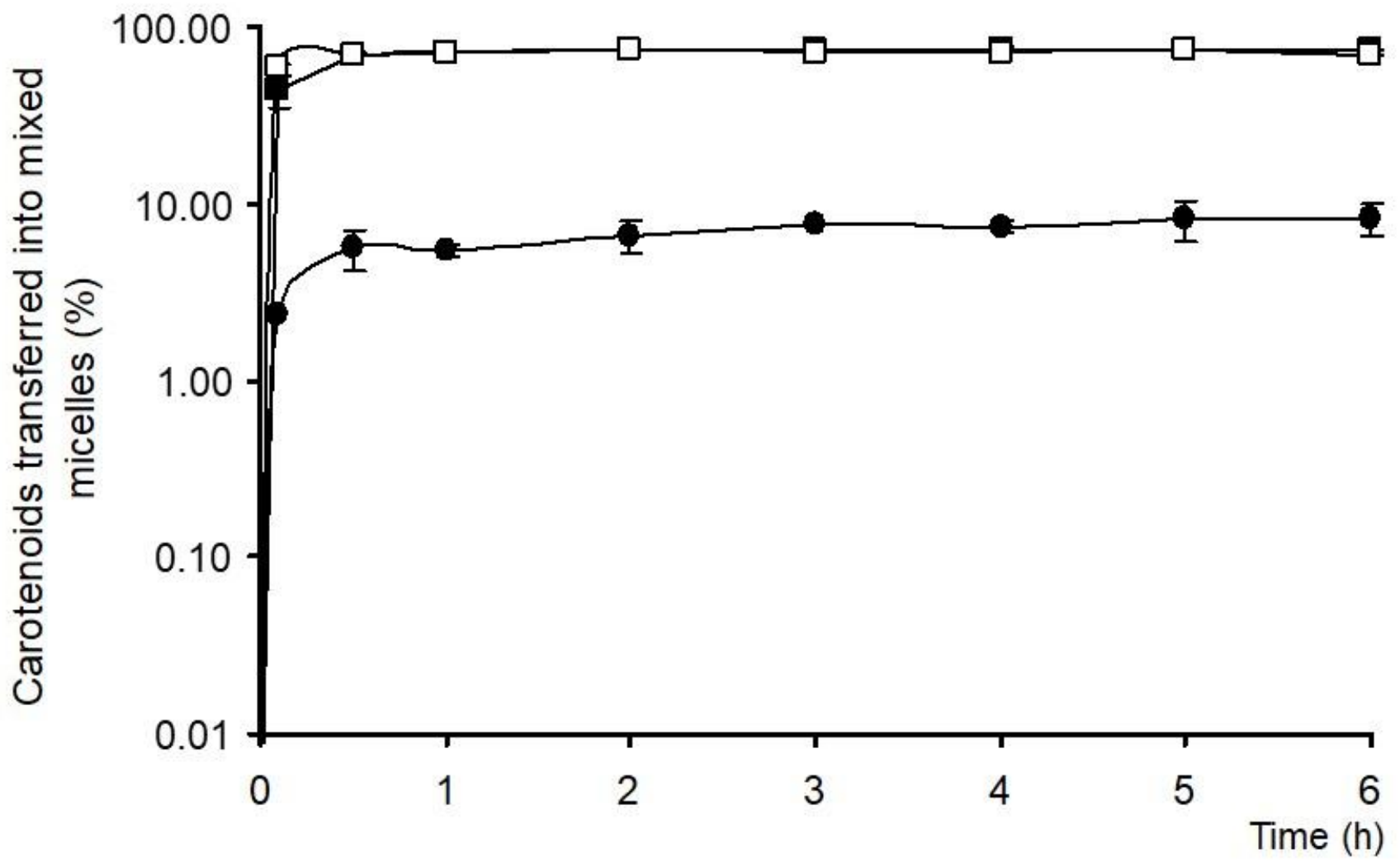

Figure 6: Amount of pure carotenoids transferred from carotenoid powders to synthetic mixed micelles solubilized in water as a function of time. (@) Pure $\beta$-carotene, $(\boldsymbol{\square})$ purified HU36 carotenoids and $(\square)$ purified GB1 carotenoids. Experiments performed protected from light at $37^{\circ} \mathrm{C}$. Means $\pm \mathrm{SD}$ of three independent experiments. 


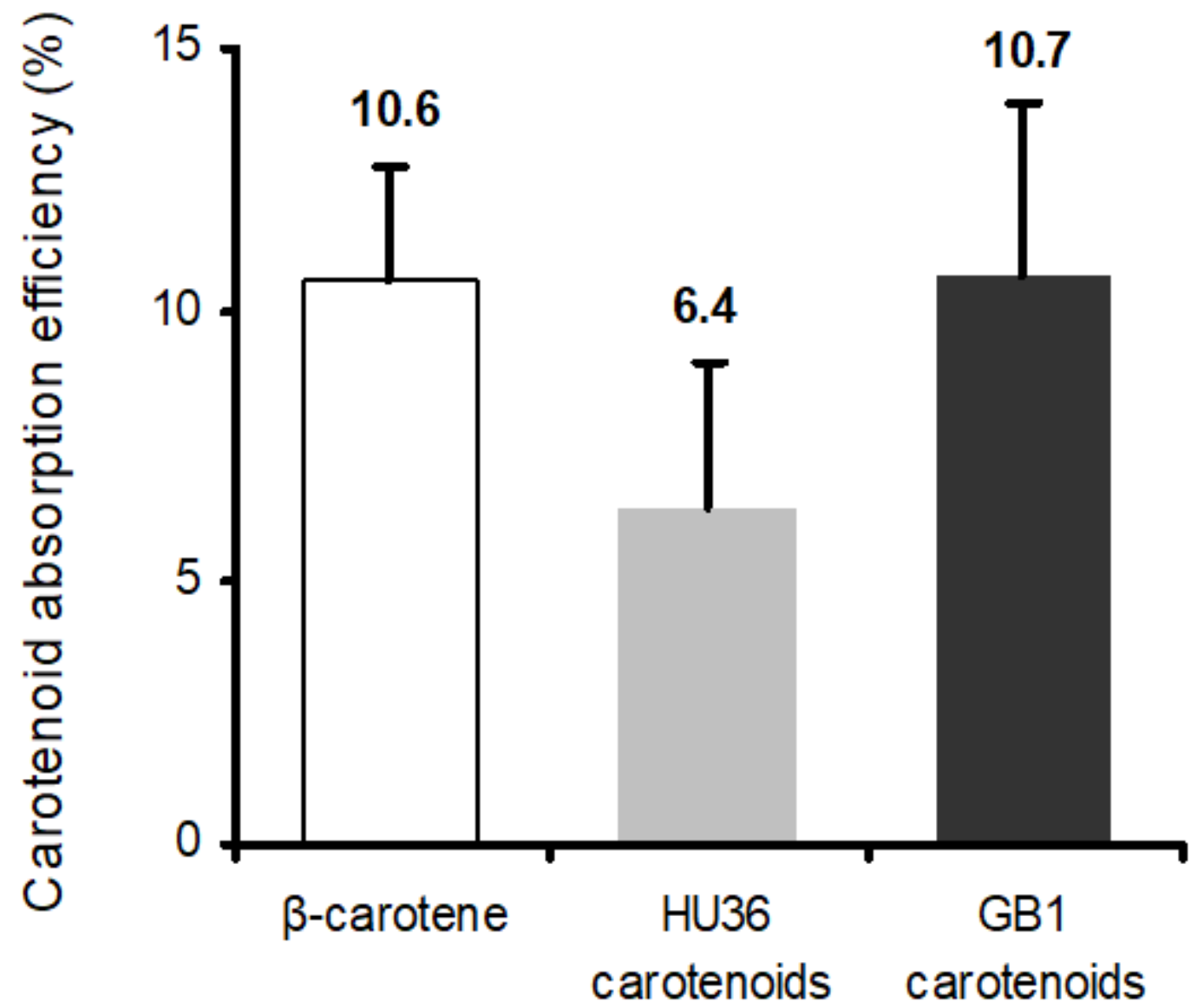

Figure 7: Uptake, by Caco-2 cell monolayers, of carotenoids incorporated in mixed micelles that came from in vitro digestion experiments, expressed as uptake efficiency (\% of the carotenoid amount added onto cell monolayers). Means \pm SD of three independent experiments. There was no significant $(P<0.05)$ differences between means (ANOVA and Tukey-Kramer test). 


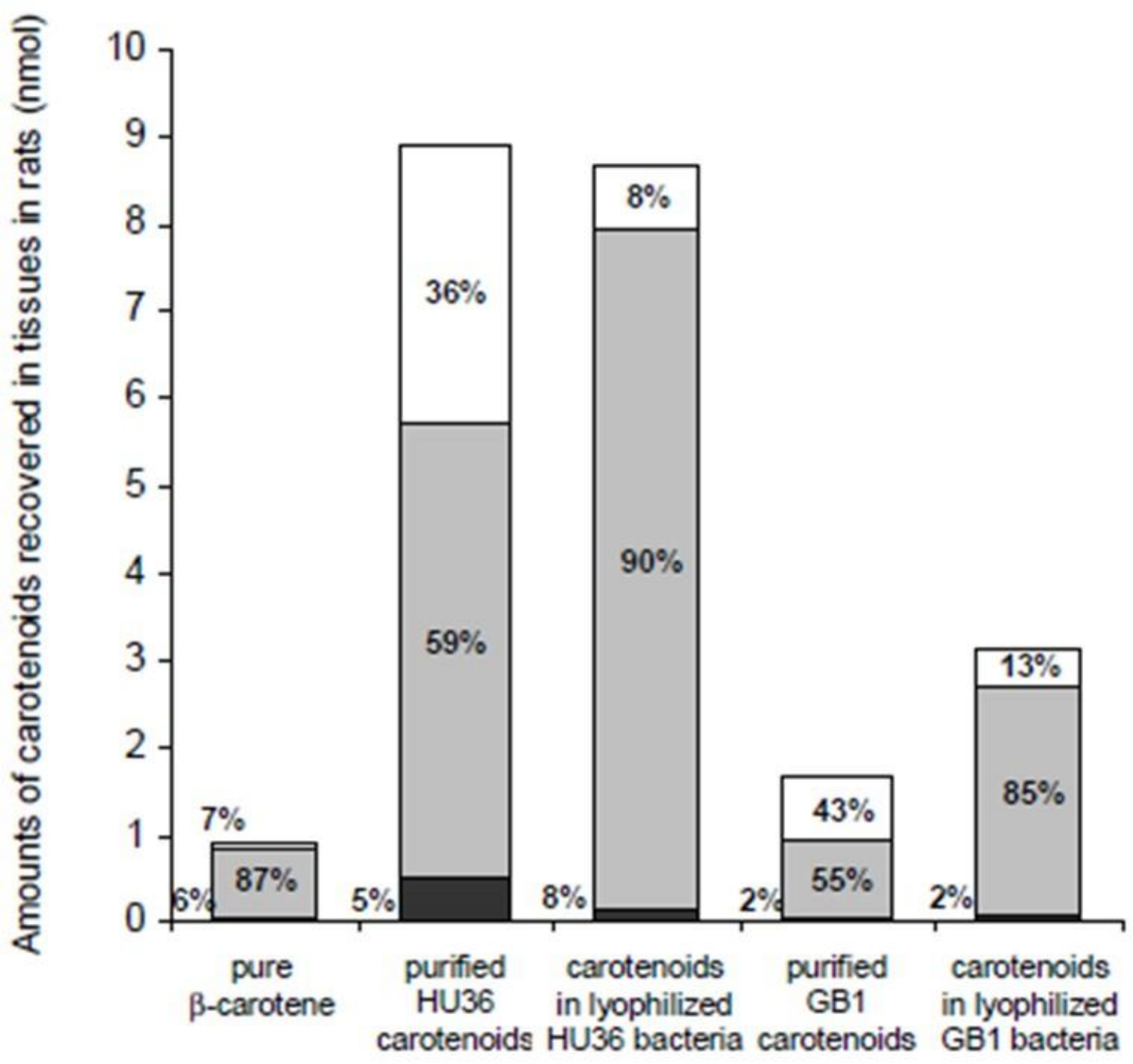

Figure 8: Amounts of carotenoids recovered in rat tissues after Wistar rats were force-fed for 3 days with either purified carotenoids or carotenoids in lyophilized bacteria. Numbers show the relative distributions $(\%)$ of these carotenoids between plasma (black section), liver (grey section) and adipose tissue (white section). 